\title{
The Research of Agricultural SMEs Credit Risk Assessment Based on the Supply Chain Finance
}

\author{
Zeping Tong ${ }^{1, *}$, Shuo Yang ${ }^{1}$ \\ ${ }^{1}$ Business Administration, Evergrande School of Management, Wuhan University of Science and Technology, China
}

\begin{abstract}
Agriculture is a basic industry that supports the construction and development of the national economy and plays an important role in promoting rural revitalization. And in the current post-COVID-19 era, agricultural SMEs have difficulty in obtaining the favours of financial institutions in normal lending due to their weak credit guarantee capabilities and high credit management costs. Difficulty in financing has become a bottleneck problem that plagues the development of enterprises and restricts the development of agricultural modernization. How to evaluate and control its credit risk is not only a major way to solve the financing difficulties of agricultural SMEs, but also the basis for the stable development of supply chain financial services. This paper analyzes three typical financing modes of agricultural SMEs from the perspective of supply chain finance, and takes the agricultural SMEs in the New OTC Market as an example to construct a Logistic model, and uses factor analysis to effectively predict the credit risk of supply chain finance. The results show that the operational efficiency factors, growth factors and related core corporate profitability of agricultural SMEs financing enterprises significantly affect their credit risk. After testing, the model is highly accurate in predicting the financing risks of agricultural SMEs.
\end{abstract}

\section{Introduction}

Agriculture as the first industry is the foundation stone of the Chinese national economy. According to the China Agricultural Industry Development Report 2019, agriculture has contributed $23.3 \%$ for GDP in the national economy, and contributed more than $1 / 3$ of employment, reaching $36.7 \%$. As an important part of agriculture, agricultural SMEs play an important role in expanding employment, promoting agriculture, rural construction and promoting rural revitalization ${ }^{[1]}$. With the accelerating process of agricultural industrialization and modernization in China, the proportion of agricultural mechanization and agricultural product processing industry has been increasing, but the corresponding financial system has not been improved, and the current situation of financing difficulties and insufficient funds has greatly restricted agricultural development and rural revitalization. Compared with other industries, agricultural small and medium-sized enterprises have a long production cycle, easy to be affected by natural conditions, poor ability to resist risks and imperfect financial statements due to their own weakness. These circumstances lead to high financing costs and increase the difficulty of financing. Especially since the outbreak of COVID-19, the impact on agricultural development is huge. In the circulation of agricultural products, export and other links caused a huge impact, agricultural small and micro enterprises operating crisis superimposed, financial supply and demand contradiction further sharpened, resulting in their financing situation is more severe. Based on this situation, supply chain finance as an effective way to solve the financing problems of agricultural SMEs has been widely concerned by the theoretical and industrial circles ${ }^{[2]}$.

Supply chain finance is the intersection of supply chain and finance ${ }^{[3]}$. It can be understood as a financial service in which banks manage the capital flow and logistics of upstream and downstream small and mediumsized enterprises around the core enterprises, turn the uncontrollable risk of a single enterprise into the controllable risk of the whole supply chain enterprise, and control the risk to the minimum ${ }^{[4]}$. Different from the traditional bank lending which focuses on the credit and debt paying ability of the lending enterprises, supply chain finance lays more emphasis on the transaction credit of the lending enterprises based on the whole supply chain network structure ${ }^{[5]}$. As the financing participants in agricultural supply chain finance are more and the scope is larger, the difficulty of identifying its credit risk will be greatly enhanced. In addition, based on the characteristics of credit addition and risk diversification of supply chain finance model and the complex characteristics of participants, the credit risk in the financing process of agricultural supply chain finance is different from the credit risk of traditional bank credit financing. Therefore, how to evaluate and control the credit risk of participating enterprises based on the network structure of the entire agricultural supply chain will be a key factor affecting the development of agricultural supply chain finance. 


\section{Literature review}

\subsection{Analysis of assessment indicators for supply chain financial credit risks}

Many scholars have carried out a large number of studies on the assessment indicators of credit risk in supply chain finance. Blame \& Schoenherr used the transaction cost theory to analyze the influencing factors of risk management in supply chain finance, and used these influencing factors to select indicators to establish a risk assessment system ${ }^{[6]}$. Xiong Xiong, Ma Jia et al believe that supply chain finance adopts the integrated method of subject rating and debt rating, and considers the influence of factors such as enterprise quality, operation ability and development prospect on the credit risk assessment system of small and medium-sized enterprises ${ }^{[7]}$. Xia Liming and Zong Hengheng et al. selected the credit risk assessment indicators of supply chain finance from the three influencing factors of financing subject, financing debt and financing macro environment, and determined the credit risk assessment indicator system of small and medium-sized enterprises from the perspective of supply chain finance through questionnaire design, expert scoring method and other qualitative indicators ${ }^{[8]}$. Yang Xin et al. selected assessment indexes of credit risk of supply chain finance from four aspects of supply chain operation condition, applicant qualification, assets under financing and counterparty qualification ${ }^{[9]}$. Based on the availability of indicators, Niu Sihu et al. selected four aspects, including internal business process, finance, learning and growth, and customers, to construct a credit assessment index system for SMEs under the supply chain finance model ${ }^{[10]}$.

\subsection{Construction of credit risk assessment model of supply chain finance}

As for the construction of credit risk assessment model of supply chain finance, most domestic and foreign scholars use statistical analysis credit risk method represented by Logistic model or mathematical credit risk assessment method based on BP neural network model. Hu Haiqing et al, using SVM and BP neural network algorithm as a supply chain finance credit risk assessment model, indicating that the SVM assessment is bette ${ }^{\mathrm{r}}{ }^{[1]}$. Su and Lu designed a simulation model for supply chain finance based on Simon's bounded rationality model to simulate the credit risks of supply chain finance of commercial banks, SMEs and storage companies, providing a basis for commercial banks to evaluate the credit risks of small and medium-sized enterprises before lending [12]. Zhou Wenkun and Wang Chengfu used the assessment method combining DEA, AHP and fuzzy TOPSIS based on leftright score to evaluate the credit risk of SMEs in supply chain financing ${ }^{[13]}$. Shan Miyuan selected supply chain enterprises in the steel and pharmaceutical industries as data samples, and calculated the credit risk of enterprises through KMV model ${ }^{[14]}$. Tian Meiyu took the automotive industry as an example, using entropy rights law to make credit assessment of SMEs, solved the subjective defects of practitioners ${ }^{[15]}$. Hou Bo is designed as a sample, from the four aspects of financing enterprises, core enterprises, supply chain health and financing model, and uses the Logistic model to effectively evaluate supply chain financial credit risk ${ }^{[16]}$. Yu Desheng established a risk control model by empirically analyzing the listed companies in the electronics manufacturing industry and using the Logistic model in combination with the data of these listed companies, and finally concluded that the model had a high applicability in the electronics manufacturing industry ${ }^{[17]}$. By studying the supply chain business data of supply chain financial service providers (FSP) in the mobile communication industry, Song Hua verified that supply chain information had a significant positive impact on supply chain rating and financing, and took this conclusion as an important basis for supply chain credit rating ${ }^{[18]}$. Based on the framework of agricultural supply chain finance credit risk causation analysis system, $\mathrm{Li}$ Guorong constructed structural equation model, analyzed the influencing factors of credit risk, and drew suggestions for optimizing credit problems ${ }^{[19]}$. Shao Lantong used the research method of system dynamics to carry out simulation analysis to study the three financial modes of agricultural supply chain and put forward relevant optimization suggestions ${ }^{[20]}$.

In view of this, it is of great theoretical and practical significance to study the credit risk assessment of SME in supply chain finance. In terms of credit risk indicators of supply chain finance, most scholars consider them based on financing subjects and financing debts, and seldom consider them from the perspective of the whole supply chain. In addition, most of the current scholars' researches on credit risk assessment of supply chain finance focus on several major industries such as electronic manufacturing industry, automobile industry and medicine industry, and there are few researches on agricultural industry. In the literature involved in agricultural supply chain finance is often qualitative description of agricultural supply chain finance model and the problems faced by agricultural supply chain finance or solutions and other problems, few of the risk situation of agricultural supply chain finance using mathematical model for quantitative analysis. However, due to the large seasonal influence of agriculture and its own characteristics of weakness, it is more necessary to evaluate and control its credit risk in the supply chain. To sum up, it is of certain significance to study the credit risk assessment of supply chain finance in agricultural industry.

Based on the process and business model of agricultural supply chain finance, this paper firstly analyzes the influencing factors of credit risk, and builds the credit risk assessment index system of agricultural small and medium-sized enterprises in supply chain finance business on this basis. Previous scholars have selected sample enterprises from the Mainboard and the Growth Enterprise Board, but such sample enterprises are not very consistent with small and medium-sized enterprises under the supply chain finance model. Therefore, this paper takes 35 agricultural small and medium-sized enterprises in the New OTC Market as samples to study their credit risks in supply chain finance, and uses Logistic regression to establish a credit risk 
assessment model for agricultural small and mediumsized enterprises in supply chain finance, in order to provide new theoretical ideas for whether commercial banks should give credit to financing enterprises.

\section{Credit risk analysis of agricultural supply chain finance}

\subsection{Definition and business model of agricultural supply chain finance}

Similar to supply chain finance, the operation process of agricultural supply chain finance is actually the production supply and marketing process. It can effectively integrate the logistics, capital flow and information flow involved in all nodes of raw materials procurement, production links (planting and farming), deep processing of agricultural products, distribution links of agricultural products, and agricultural products, etc., and finally connect each link into a chain to make it an overall function ${ }^{[20]}$.

The key of agricultural supply chain finance to solve the financing dilemma of SMEs is that it takes the credit of leading enterprises in the industry as the core and extends it to the whole agricultural supply chain. With the credit of leading enterprises as the guarantee, it conducts closed credit granting activities for SMEs in the supply chain, so as to increase the bank's trust in agricultural customers and reduce the credit risk of agricultural SMEs. Finally, it will achieve a win-win situation for the related subjects in various aspects, such as the increase of commercial banks' profits, the reduction of financing transaction costs of agricultural SMEs, the competitiveness of related core enterprises will be enhanced, and the business scope of logistics enterprises will be expanded.

The agricultural supply chain mainly includes four processes: production, processing, distribution and finally flowing into the consumer market. Thus, the business models of the agricultural supply chain can be divided into three types: confirmed storage financing model, FTW financing model, and accounts receivable financing $\operatorname{model}^{[21]}$.

(1) Confirmed storage financing mode: It is also called prepayment financing mode, which is mainly used in the raw material procurement stage of agricultural supply chain. When the core enterprise in the upstream of the supply chain is relatively strong, the SMEs in the downstream will be forced to generate prepayment for partial or all payment of raw materials in advance. The downstream agricultural SMEs will be in trouble due to the purchase of a large amount of funds resulting in insufficient capital flow.

Under the confirmed storage financing mode, the downstream agricultural SMEs can obtain loans from the bank by pledging the delivery right of the pre-purchased agricultural products, and pay the corresponding margin to the bank to take delivery. The upstream core enterprise will send the goods to the third-party logistics enterprises or warehousing companies designated by the bank according to the instructions of the bank, and provide repurchase guarantee for small and medium-sized financing enterprises. The third-party logistics enterprises or warehousing companies provide storage supervision services for banks and deliver goods to SMEs according to the instructions of banks. As for commercial banks, they are responsible for providing loans to enterprises and collecting a certain amount of deposit, and issue the same amount of release notice to the third-party logistics or warehousing company according to the amount of loan repayment. The confirmed storage financing mode can be reflected in Figure 1.

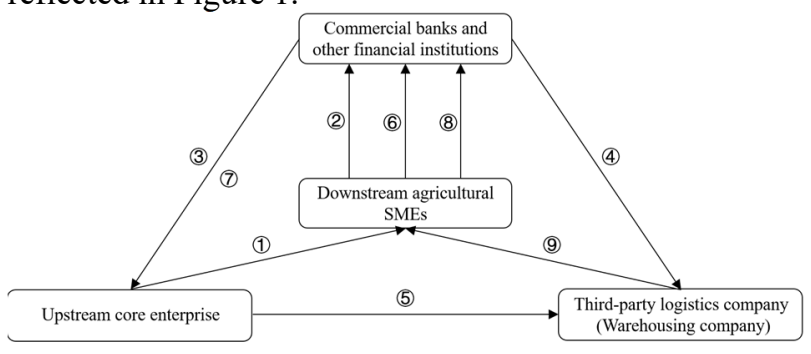

Figure 1. Confirmed storage financing model process.

Table1. Operation process description of confirmed storage financing model.

\begin{tabular}{|c|l|}
\hline $\begin{array}{c}\text { Step } \\
\text { number }\end{array}$ & $\begin{array}{l}\text { The description of the process represented } \\
\text { by the step number }\end{array}$ \\
\hline 1 & Sign the purchase and sale contract \\
\hline 2 & Apply for credit \\
\hline$(3)$ & Sign a repurchase agreement \\
\hline (4) & Sign a warehousing supervision agreement \\
\hline 5 & Ship and get the warehouse receipt \\
\hline (6) & Pay margin \\
\hline 7 & $\begin{array}{l}\text { The warehouse receipt is pledged to the } \\
\text { bank, and the bank issues an acceptance } \\
\text { draft }\end{array}$ \\
\hline 8 & Repayment and get the right of delivery \\
\hline 9 & Unsecured goods \\
\hline
\end{tabular}

(2) FTW financing model: It is mainly used in the agricultural production stage of the agricultural supply chain. When the market is depressed or the logistics operation is not smooth during the epidemic, the sales of agricultural products will drop sharply, and the semifinished products and inventories of the enterprise will occupy a large amount of working capital, resulting in the shortage of capital flow of the enterprise.

Under the FTW financing model, commercial banks, SMEs and logistics enterprises sign a warehousing supervision agreement, and the upstream agricultural SMEs take their inventories as pledge and apply for loans from commercial banks with the inventories and the income generated as the first source of repayment. Commercial banks provide loans. The third-party logistics evaluates and supervises the agricultural products inventory submitted by SMEs for commercial banks and carries out the later distribution after the repayment. The FTW financing model can be reflected in Figure 2. 


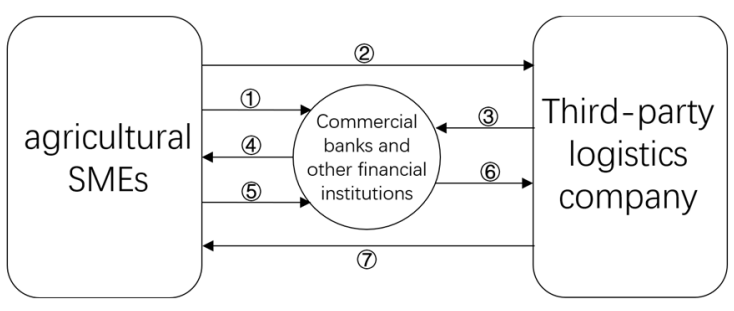

Figure 2. FTW financing model process.

Table2. Operation process description of FTW financing model.

\begin{tabular}{|c|l|}
\hline $\begin{array}{c}\text { Step } \\
\text { number }\end{array}$ & $\begin{array}{l}\text { The description of the process represented by } \\
\text { the step number }\end{array}$ \\
\hline 1 & apply for a loan \\
\hline 2 & Storing the pledge into the warehouse \\
\hline$(3$ & Show proof of pledge \\
\hline 4 & Issue a loan \\
\hline 5 & Repay the loan \\
\hline 6 & Inform SMEs of the right of delivery \\
\hline 7 & Send pledged goods \\
\hline
\end{tabular}

(3) Accounts receivable financing model: It is mainly used in the agricultural product sales stage of the agricultural supply chain. In the agricultural supply chain, the downstream core enterprises are relatively strong and often require to postpone the payment for their goods. Therefore, the upstream agricultural SMEs often sell on credit in order to improve their market share and sales volume, and the SMEs can only get accounts receivable on their books. In the case of its own capital is insufficient, these enterprises will have a serious shortage of funds.

Under the accounts receivable financing model, Core enterprises provide credit guarantee, while agricultural small and medium-sized enterprises pledge or directly transfer receivables based on real trade contracts to commercial banks, so as to obtain credit support from banks. The accounts receivable model can be reflected in Figure 3.

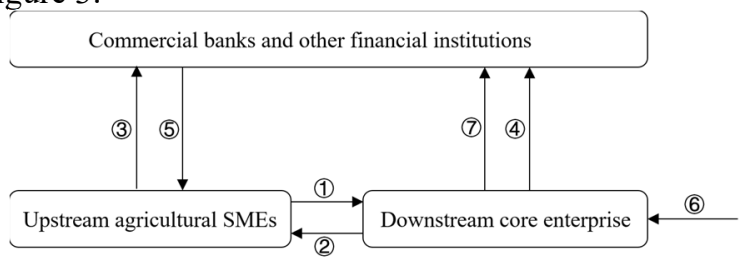

Figure 3. accounts receivable financing model.

Table3. Operation process description of accounts receivable financing model.

\begin{tabular}{|c|l|}
\hline $\begin{array}{c}\text { Step } \\
\text { number }\end{array}$ & $\begin{array}{l}\text { The description of the process represented by } \\
\text { the step number }\end{array}$ \\
\hline (1) & $\begin{array}{l}\text { Sign the relevant goods sales contract and } \\
\text { deliver the goods }\end{array}$ \\
\hline 2 & Issue accounts receivable documents \\
\hline 3 & Pledge accounts receivable documents \\
\hline (4) & $\begin{array}{l}\text { Issuing proof of documents and payment } \\
\text { undertaking }\end{array}$ \\
\hline (5) & Issue a loan \\
\hline 6 & Sales collection \\
\hline 7 & Repay the loan \\
\hline
\end{tabular}

\subsection{Credit risk source of agricultural supply chain finance}

Through the above analysis of the three business models of agricultural supply chain finance, it can be seen that the credit risks of SMEs in the agricultural supply chain are mainly influenced by the following aspects:

\subsubsection{Influencing factors of SMEs' own conditions}

SMEs are the main body of financing, and it can only be credited to the relevant core enterprises with their own strength. Factors affecting their own strength of SMEs mainly include profitability, operational capacity, solvency, growth capacity.

The profitability of the company refers to the ability to create profit in the production and operation process. It fluctuates the business performance and management capabilities of the company. It can be roughly judged from whether the company can obtain enough funds to repay the debts. The profitability of an enterprise is usually reflected by financial indicators such as the rate of return on total assets (ROA), the rate of return on equity (ROE), and the net profit rate on sales.

Operation capacity refers to the operation and operation capacity of an enterprise, which means the ability of an enterprise to make profits by using existing assets for production and operation. The stronger the operating capacity, the faster the capital turnover of the enterprise. The faster the capital turnover, the stronger the solvency of the enterprise and the smaller the credit risk. The operating capacity of an enterprise is usually reflected by financial indicators such as total asset turnover ratio, receivables turnover ratio, fixed assets turnover, inventory turnover and current assets turnover.

Solvency refers to the ability of an enterprise to repay debts. It is the index that can best represent the level of credit risk of an enterprise, so it is the most important index of enterprise credit assessment. An enterprise with strong solvency indicates that its capital is used efficiently and its debts are used to the maximum extent for the production and operation services of the enterprise. The solvency of enterprises is usually reflected by the current ratio, quick ratio, debt asset ratio and other financial indicators.

Growth capacity is an important condition for SMEs to maintain the sustainability of profitability and solvency. Since the operating conditions of enterprises are constantly changing, the future solvency should also be taken into consideration in the credit risk assessment of enterprises. Financial indicators such as main business's increasing rate of income, net profit growth rate and total assets growth rate can reflect the growth ability of an enterprise.

\subsubsection{Asset quality condition under financing}

Raw materials, inventories, finished products and other assets owned by financing enterprises are the major concerns of commercial banks and other financial institutions. First of all, these assets will become a 
necessary condition for the bank to grant credit. Secondly, in case of a default event in supply chain finance, the bank can make up for its loss by relying on timely realization of these assets, while the amount of realization recovery mainly depends on the quality of the collateral assets themselves. In this paper, the quality of assets under financing items is mainly considered inventory quality, quality of accounts receivable, quality of prepaid accounts.

\subsubsection{The conditions of the related core enterprises in the supply chain}

The core enterprise is the leading enterprise in the whole supply chain operation and plays a core role. Supply chain finance business is based on the real trade background, the core enterprises and small and medium-sized financing enterprises have relatively frequent business dealings, because of the core enterprises to guarantee small and medium-sized enterprises, so small and medium-sized enterprises are easier to obtain loans. Therefore, the credit status of core enterprises also affects the credit risk of SMEs in the supply chain to a large extent ${ }^{[22]}$. In this paper, the credit status of core enterprises is mainly considered from two aspects: profitability and solvency.

\subsubsection{Supply chain relationship status}

Supply chain finance is based on the real trade relationship, and the repayment method of financing enterprises is based on the self-compensating trade financing theory. They take the sales revenue generated in the chain as the direct source of repayment, so the relationship status of supply chain plays a very important role in whether SMEs can fulfill the repayment agreement. When the supply chain operates in good condition and the cooperation between enterprises is stable and frequent, the relationship between the supply chain will be relatively stable and the credit risk of SMEs will be reduced. This paper reflects the frequency of cooperation through the accounts receivable or the proportion of annual sales between SMEs and core enterprises.

\subsection{Construction of credit risk assessment index system}

Based on the detailed analysis of the source factors of credit risk for small and medium-sized enterprises in agricultural supply chain finance, and referring to the credit risk assessment index system of small and mediumsized enterprises in the traditional banking business and the research results of previous scholars, the credit risk assessment index system of small and medium-sized enterprises in supply chain finance is constructed as shown in Table 1. In the process of establishing the index system, this paper follows the principles of comprehensiveness, pertinence and operability. In order to present the composition of the assessment index system in a more scientific, reasonable and comprehensive way, we set up the first-level indicators, second-level indicators and third-level indicators respectively, and spread them out step by step for classification and summary.

In Table 4, the established credit risk assessment index system for small and medium-sized enterprises in agricultural supply chain finance mainly includes four parts: SMEs' own conditions, asset quality condition under financing, the conditions of related core enterprises, and the supply chain relationship status. These four parts are the main sources of credit risks for SMEs. Among them, SMEs' own conditions mainly include profitability, operating capacity, solvency and growth capacity. Assets under financing items mainly include inventory quality and account quality. Core enterprise factors include core enterprise profitability and solvency. The supply chain situation mainly considers the cooperation stability in the supply chain, namely the cooperation frequency.

Table4. Agricultural supply chain finance credit risk assessment index system.

\begin{tabular}{|c|c|c|c|}
\hline $\begin{array}{l}\text { First-level } \\
\text { indicators }\end{array}$ & $\begin{array}{l}\text { Second-level } \\
\text { indicators }\end{array}$ & Three-level indicators & Indicator description \\
\hline \multirow{11}{*}{$\begin{array}{l}\text { SMEs' own } \\
\text { conditions }\end{array}$} & \multirow{3}{*}{ Profitability } & $\mathrm{ROA} \mathrm{X}_{1}$ & Net profit/Average balance of total assets \\
\hline & & $\mathrm{ROE} \mathrm{X}_{2}$ & Net profit/Net assets \\
\hline & & Net profit margin on sales $\mathrm{X}_{3}$ & Net profit/Sales revenue \\
\hline & \multirow{4}{*}{ Operating capacity } & Total asset turnover ratio $\mathrm{X}_{4}$ & $\begin{array}{l}\text { Net operating income/Average balance of } \\
\text { total assets }\end{array}$ \\
\hline & & Receivables turnover ratio $\mathrm{X}_{5}$ & $\begin{array}{l}\text { Sales revenue/Average balance of } \\
\text { accounts receivable }\end{array}$ \\
\hline & & Inventory turnover $\mathrm{X}_{6}$ & $\begin{array}{l}\text { Main business cost/Average inventory } \\
\text { balance }\end{array}$ \\
\hline & & Current assets turnover $\mathrm{X}_{7}$ & $\begin{array}{l}\text { Main business income/Average total } \\
\text { current assets }\end{array}$ \\
\hline & \multirow{3}{*}{ Solvency } & Current ratio $\mathrm{X}_{8}$ & Current assets/Current liability \\
\hline & & Quick ratio $\mathrm{X}_{9}$ & Quick assets/Current liability \\
\hline & & Debt asset ratio $\mathrm{X}_{10}$ & Total liabilities/Total assets \\
\hline & Growth ability & $\begin{array}{l}\text { Main business's increasing rate of } \\
\text { income } X_{11}\end{array}$ & $\begin{array}{l}\text { Increase in operating income this } \\
\text { year/Last year's operating income }\end{array}$ \\
\hline
\end{tabular}




\begin{tabular}{|c|c|c|c|}
\hline & & Net profit growth rate $X_{12}$ & $\begin{array}{l}\text { Net profit growth this year/Last year's net } \\
\text { profit }\end{array}$ \\
\hline & & Total assets growth rate $\mathrm{X}_{13}$ & $\begin{array}{l}\text { Growth in total assets this year/Total } \\
\text { assets at the beginning of last year }\end{array}$ \\
\hline \multirow{3}{*}{$\begin{array}{l}\text { Asset quality } \\
\text { condition }\end{array}$} & $\begin{array}{l}\text { Pledge } \\
\text { characteristics }\end{array}$ & Inventory quality condition $\mathrm{X}_{14}$ & $\begin{array}{l}\text { Inventory as a proportion of total } \\
\text { assets*Asset impairment loss }\end{array}$ \\
\hline & \multirow{2}{*}{$\begin{array}{l}\text { Account } \\
\text { characteristics }\end{array}$} & Quality of accounts receivable $\mathrm{X}_{15}$ & $\begin{array}{l}\text { The aging analysis of accounts receivable } \\
\text { reflects the proportion of accounts } \\
\text { receivable within one year }\end{array}$ \\
\hline & & Quality of prepaid accounts $\mathrm{X}_{16}$ & $\begin{array}{l}\text { The aging analysis of prepaid accounts } \\
\text { reflects the proportion of prepaid } \\
\text { accounts within one year }\end{array}$ \\
\hline \multirow{4}{*}{$\begin{array}{l}\text { Core business } \\
\text { status }\end{array}$} & \multirow{2}{*}{ Profitability } & ROE $\mathrm{X}_{17}$ & Net profit/Net assets \\
\hline & & Net profit margin on sales $\mathrm{X}_{18}$ & Net profit/Sales revenue \\
\hline & \multirow{2}{*}{ Solvency } & Current ratio $\mathrm{X}_{19}$ & Current assets/Current liability \\
\hline & & Debt asset ratio $\mathrm{X}_{20}$ & Total liabilities/Total assets \\
\hline Supply chain status & $\begin{array}{l}\text { Cooperative } \\
\text { stability }\end{array}$ & Cooperation frequency $\mathrm{X}_{21}$ & $\begin{array}{l}\text { Proportion of accounts receivable/prepaid } \\
\text { in total or annual sales proportion }\end{array}$ \\
\hline
\end{tabular}

\section{Supply chain finance credit risk assessment of agricultural SMEs based on Logistic model}

\subsection{Model construction}

This paper uses the previous research to establish Logistic model to assess the credit risk of agricultural supply chain finance. The Logistic regression model can be expressed as $p_{j}=\frac{1}{1+e^{-z_{j}}}$, where $Z_{j}=a_{0}+\sum_{i=k}^{m} \alpha_{k} X_{k}, \mathrm{X}_{\mathrm{k}} \quad(\mathrm{k}=1$, $2 \ldots \mathrm{m})$, is the influence variable in the credit risk assessment of supply chain finance, and $\alpha_{i}(\mathrm{i}=1,2 \ldots \mathrm{m})$ is the technical coefficient, which can be obtained by regression or maximum likelihood estimation.

\subsection{Model construction}

As the New OTC Market is a national equity trading platform for non-listed limited stock companies mainly targeting at small, medium and micro enterprises, the sample enterprises selected from the trading market are more suitable for small and medium-sized enterprises in supply chain finance business. This paper takes 35 agricultural SMEs from the New OTC Market as samples, selects the financial data of the three years from 2017 to 2019 and conducts classified processing. The financial data used in this paper came from Wind database, and Stata software was used for Logistic regression analysis.

\subsection{Factor analysis}

This paper involves 21 indicators of 35 listed companies, and the explanatory variables can be retained in the model to the maximum extent by extracting principal component factors, so as to achieve the effect of dimensionality reduction. Therefore, this paper first carries out factor analysis on these 21 indicators and synthesizes them into several unrelated indicators that contain most of the information of the original indicators.

\subsubsection{KMO and Bartlett's test}

In statistical analysis, the requirement of independent variables is to avoid multicollinearity as much as possible, so as not to bring the independent variables with strong correlation into the model and affect the credibility of the model. In this paper, KMO and Bartlett's test are used to investigate whether there is a certain linear relationship between variables and whether factors can be extracted by factor analysis. The test results are shown in Table 5.

Table5. KMO and Bartlett's test.

\begin{tabular}{|l|l|l|}
\hline \multicolumn{2}{|c|}{$\begin{array}{l}\text { Kaiser-Meyer-Olkin measure of sampling } \\
\text { adequacy }\end{array}$} & 0.657 \\
\hline \multirow{3}{*}{$\begin{array}{l}\text { Bartlett's test of } \\
\text { sphericity }\end{array}$} & $\begin{array}{l}\text { Approximate chi- } \\
\text { square }\end{array}$ & 1279.744 \\
\cline { 2 - 3 } & df & 210 \\
\cline { 2 - 3 } & Sig & 0.000 \\
\hline
\end{tabular}

It is generally believed that a KMO value above 0.9 indicates that it is very suitable for factor analysis; a value between 0.8 and 0.9 indicates that it is more suitable for factor analysis; a value between 0.6 and 0.8 indicates that it is suitable for factor analysis, and a value below 0.5 indicates that it is not suitable for factor analysis. The $\mathrm{KMO}$ value obtained in this paper is 0.657 , indicating that factor analysis of the above variables can be performed. The significance of Bartlett's test is 0.000, which means that there is a certain correlation between the 21 variables. And the factor analysis will be directly performed.

\subsubsection{Extraction of factors}

Since there are 21 financial indicators selected in the sample data, the number is a little too much, so this article 
selects factor analysis to synthesize the above indicators. In the process of factor analysis, this paper selects indicators with eigenvalues greater than 1 for analysis, and extracts a total of 8 principal factors, and their cumulative variance contribution rate reaches $76.54 \%$. This paper selects $F_{1}, F_{2}, F_{3}, F_{4}, F_{5}, F_{6}, F_{7}, F_{8}$ as the final indicators for analysis.

Table6. Explanation of total variance.

\begin{tabular}{|c|c|c|c|}
\hline Factors & Eigenvalue & Proportion & Cumulative \\
\hline 1 & 4.5672 & 21.75 & 21.75 \\
\hline 2 & 2.6471 & 12.61 & 34.35 \\
\hline 3 & 2.2627 & 10.77 & 45.13 \\
\hline 4 & 1.8289 & 8.71 & 53.84 \\
\hline 5 & 1.3643 & 6.50 & 60.33 \\
\hline
\end{tabular}

\begin{tabular}{|l|l|l|l|}
\hline 6 & 1.2421 & 5.91 & 66.25 \\
\hline 7 & 1.1551 & 5.50 & 71.75 \\
\hline 8 & 1.0051 & 4.79 & 76.54 \\
\hline
\end{tabular}

\subsubsection{Factors explanation}

It can be seen from table 6 that after factor analysis of the above 21 variables, a total of 8 main factors are extracted, but each variable can be explained by multiple factor variables, which leads to each factor variable cannot fully explain the original variables, making the meaning of a dependent variable ambiguous. Therefore, this paper solves this problem by rotating the factor load matrix. According to table 7, the eight main factors are explained economically.

Table7. Factor load matrix after rotation.

\begin{tabular}{|c|c|c|c|c|c|c|c|c|}
\hline Variable & $\mathrm{F}_{1}$ & $\mathrm{~F}_{2}$ & $\mathrm{~F}_{3}$ & $\mathrm{~F}_{4}$ & $\mathrm{~F}_{5}$ & $\mathrm{~F}_{6}$ & $\mathrm{~F}_{7}$ & $\mathrm{~F}_{8}$ \\
\hline $\mathrm{X}_{1}$ & 0.8431 & 0.1114 & 0.0609 & -0.0112 & -0.0852 & 0.1445 & 0.1012 & -0.0451 \\
\hline $\mathrm{X}_{2}$ & 0.8418 & -0.0057 & 0.0394 & 0.0251 & -0.0171 & 0.1138 & 0.2398 & -0.1209 \\
\hline $\mathrm{X}_{3}$ & 0.8496 & 0.1357 & 0.0067 & -0.1443 & -0.003 & 0.005 & 0.1396 & 0.0721 \\
\hline $\mathrm{X}_{4}$ & 0.0281 & -0.0063 & 0.6749 & 0.1804 & 0.0178 & 0.1336 & -0.0185 & 0.1168 \\
\hline $\mathrm{X}_{5}$ & -0.177 & 0.0323 & 0.0615 & -0.1025 & -0.0749 & 0.0706 & -0.9233 & -0.0092 \\
\hline $\mathrm{X}_{6}$ & 0.0168 & -0.0211 & 0.0569 & 0.1463 & -0.0162 & 0.8654 & -0.0765 & -0.1098 \\
\hline $\mathrm{X}_{7}$ & 0.1542 & -0.1686 & 0.8868 & 0.0654 & 0.0073 & -0.1782 & -0.1016 & -0.2047 \\
\hline $\mathrm{X}_{8}$ & 0.1112 & 0.9659 & -0.1107 & 0.0529 & 0.0027 & -0.0687 & -0.0627 & 0.031 \\
\hline $\mathrm{X}_{9}$ & 0.0623 & 0.9713 & -0.09 & 0.0616 & 0.0084 & -0.0007 & -0.0461 & 0.0557 \\
\hline $\mathrm{X}_{10}$ & -0.1874 & -0.4739 & -0.2441 & 0.1436 & 0.0567 & 0.0289 & -0.0676 & 0.4235 \\
\hline $\mathrm{X}_{11}$ & 0.4519 & -0.0878 & 0.2835 & 0.2294 & 0.2903 & -0.0251 & 0.0144 & 0.1322 \\
\hline $\mathrm{X}_{12}$ & 0.4381 & -0.0829 & -0.0648 & 0.0278 & 0.0266 & -0.0431 & 0.7968 & 0.0848 \\
\hline $\mathrm{X}_{13}$ & 0.3318 & -0.0693 & -0.174 & -0.0872 & 0.0136 & 0.8875 & -0.0452 & -0.0137 \\
\hline $\mathrm{X}_{14}$ & -0.4877 & 0.0983 & -0.195 & 0.4863 & 0.3297 & 0.0171 & 0.1506 & -0.1962 \\
\hline $\mathrm{X}_{15}$ & 0.5013 & 0.0719 & -0.063 & 0.1676 & 0.3954 & -0.0383 & -0.3305 & 0.1054 \\
\hline $\mathrm{X}_{16}$ & -0.4138 & 0.1849 & 0.3865 & -0.1311 & 0.1646 & 0.1859 & 0.1239 & 0.3276 \\
\hline $\mathrm{X}_{17}$ & -0.1523 & -0.0504 & 0.0128 & -0.2332 & 0.8772 & 0.0101 & 0.1018 & -0.1077 \\
\hline $\mathrm{X}_{18}$ & 0.0335 & 0.0416 & 0.0434 & -0.182 & 0.8712 & -0.0036 & 0.0135 & -0.03 \\
\hline $\mathrm{X}_{19}$ & 0.1366 & -0.0508 & -0.1521 & -0.7925 & 0.1646 & -0.0109 & -0.0054 & 0.0186 \\
\hline $\mathrm{X}_{20}$ & 0.0183 & 0.0331 & 0.0607 & 0.8622 & -0.2748 & 0.0307 & 0.0915 & 0.0484 \\
\hline $\mathrm{X}_{21}$ & 0.0119 & 0.0627 & -0.0771 & 0.0072 & -0.1234 & -0.0984 & 0.0547 & 0.8893 \\
\hline
\end{tabular}

As can be seen from table 7 , there are 4 variables reflecting the profitability of SMEs, i.e. are ROA $\mathrm{X}_{1}$, ROE $X_{2}$, net profit margin on sales $X_{3}$ of SMEs and main business's increasing rate of income $\mathrm{X}_{11}$, and 3 variables reflecting the characteristics of assets under financing, i.e. Inventory quality condition $\mathrm{X}_{14}$, quality of accounts receivable $\mathrm{X}_{15}$ and quality of prepaid accounts $\mathrm{X}_{16}$, which are highly loaded in factor $F_{1}$. Therefore, $F_{1}$ is called profit and property factor of financing enterprises. The current ratio $\mathrm{X}_{8}$, quick ratio $\mathrm{X}_{9}$ and debt asset ratio $\mathrm{X}_{10}$ of SMEs, the 3 variables reflecting the solvency of small and medium-sized enterprises, have a high load on factor $F_{2}$, so $F_{2}$ is called the solvency factor of financing enterprises. The total asset turnover ratio $\mathrm{X}_{4}$ and current assets turnover $\mathrm{X}_{7}$, the 2 variables reflecting the profitability of
SMEs, have a high load on $F_{3}$, so $F_{3}$ is called the operational efficiency factor. The 2 variables reflecting the solvency of core enterprises, i.e., current ratio $\mathrm{X}_{19}$ and debt asset ratio $X_{20}$, have a high load on $F_{4}$, so $F_{4}$ is called the solvency factor of core enterprises. The ROE $\mathrm{X}_{17}$ and net profit margin on sales $\mathrm{X}_{18}$ of core enterprises, the 2 variables reflecting the profitability of core enterprises, have a high load on $F_{5}$, so $F_{5}$ is called the profitability factor of core enterprises. A variable reflecting the operating capacity of the enterprise inventory turnover rate $\mathrm{X}_{6}$ and a variable reflecting the growth capacity of the enterprise total asset growth rate $\mathrm{X}_{13}$ have a high load on factor $F_{6}$, so it is called $F_{6}$ as a comprehensive factor. The receivables turnover ratio $\mathrm{X}_{5}$ and the net profit growth rate $X_{12}$ have a high load on factor $F_{7}$. The receivables turnover 
ratio reflects the efficiency of capital use of the enterprise, and also affects the growth ability of the enterprise to a certain extent, so it is called $\mathrm{F}_{7}$ as the growth factor. The cooperation frequency $\mathrm{X}_{21}$ reflects the stability of cooperation in the supply chain, and has a high load on factor $F_{8}$, so it is called $F_{8}$ as the operation factor of the supply chain.

\subsubsection{Factors score}

Through the factor score matrix, each factor can be expressed as a linear combination of variables, so as to obtain the final score value of each factor.

Table8. Factor scoring matrix.

\begin{tabular}{|c|c|c|c|c|c|c|c|c|}
\hline Variable & $\mathrm{F}_{1}$ & $\mathrm{~F}_{2}$ & $\mathrm{~F}_{3}$ & $\mathrm{~F}_{4}$ & $\mathrm{~F}_{5}$ & $\mathrm{~F}_{6}$ & $\mathrm{~F}_{7}$ & $\mathrm{~F}_{8}$ \\
\hline $\mathrm{X}_{1}$ & 0.2399 & 0.0249 & 0.0116 & 0.0046 & 0.0357 & 0.0358 & 0.0162 & 0.0266 \\
\hline $\mathrm{X}_{2}$ & 0.2350 & 0.0267 & 0.0110 & 0.0322 & 0.0031 & 0.0148 & 0.0567 & 0.0908 \\
\hline $\mathrm{X}_{3}$ & 0.2467 & 0.0329 & 0.0113 & 0.0537 & 0.0017 & 0.0408 & 0.0031 & 0.0621 \\
\hline $\mathrm{X}_{4}$ & 0.0299 & 0.0366 & 0.4208 & 0.0372 & 0.0110 & 0.1157 & 0.0279 & 0.1356 \\
\hline $\mathrm{X}_{5}$ & 0.0404 & 0.0143 & 0.0022 & 0.0164 & 0.0156 & 0.0003 & 0.5340 & 0.0211 \\
\hline $\mathrm{X}_{6}$ & 0.0517 & 0.0181 & 0.0579 & 0.0470 & 0.0045 & 0.5254 & 0.0095 & 0.0418 \\
\hline $\mathrm{X}_{7}$ & 0.0334 & 0.0421 & 0.5089 & 0.0166 & 0.0213 & 0.1013 & 0.0369 & 0.1260 \\
\hline $\mathrm{X}_{8}$ & 0.0101 & 0.4252 & 0.0255 & 0.0136 & 0.0072 & 0.0248 & 0.0191 & 0.0167 \\
\hline $\mathrm{X}_{9}$ & 0.0144 & 0.4348 & 0.0036 & 0.0100 & 0.0085 & 0.0252 & 0.0029 & 0.0404 \\
\hline $\mathrm{X}_{10}$ & 0.0017 & 0.2367 & 0.1748 & 0.1281 & 0.0868 & 0.0094 & 0.0885 & 0.3366 \\
\hline $\mathrm{X}_{11}$ & 0.1584 & 0.0604 & 0.1174 & 0.1718 & 0.1924 & 0.0467 & 0.0705 & 0.1387 \\
\hline $\mathrm{X}_{12}$ & 0.0575 & 0.0251 & 0.0149 & 0.0071 & 0.0011 & 0.0086 & 0.4261 & 0.0451 \\
\hline $\mathrm{X}_{13}$ & 0.0520 & 0.0240 & 0.0821 & 0.0447 & 0.0032 & 0.5151 & 0.0160 & 0.0297 \\
\hline $\mathrm{X}_{14}$ & 0.1391 & 0.0411 & 0.1456 & 0.2991 & 0.2121 & 0.0196 & 0.0993 & 0.1595 \\
\hline $\mathrm{X}_{15}$ & 0.2328 & 0.0308 & 0.1228 & 0.2080 & 0.2695 & 0.0979 & 0.3123 & 0.1155 \\
\hline $\mathrm{X}_{16}$ & 0.2013 & 0.1498 & 0.3266 & 0.1417 & 0.0468 & 0.2088 & 0.1770 & 0.2943 \\
\hline $\mathrm{X}_{17}$ & 0.0509 & 0.0115 & 0.0035 & 0.0343 & 0.4156 & 0.0181 & 0.0594 & 0.0430 \\
\hline $\mathrm{X}_{18}$ & 0.0195 & 0.0156 & 0.0088 & 0.0053 & 0.4308 & 0.0053 & 0.0195 & 0.0243 \\
\hline $\mathrm{X}_{19}$ & 0.0192 & 0.0094 & 0.0378 & 0.4093 & 0.0057 & 0.0041 & 0.0176 & 0.0185 \\
\hline $\mathrm{X}_{20}$ & 0.0273 & 0.0090 & 0.0225 & 0.4456 & 0.0355 & 0.0022 & 0.0083 & 0.0251 \\
\hline $\mathrm{X}_{21}$ & 0.0114 & 0.0216 & 0.0009 & 0.0079 & 0.0152 & 0.0150 & 0.0023 & 0.7027 \\
\hline
\end{tabular}

As can be seen from table 8 ,

$\mathrm{F}_{1}=0.2399 \mathrm{X}_{1}+0.2350 \mathrm{X}_{2}+0.2467 \mathrm{X}_{3}+\ldots+0.0114 \mathrm{X}_{21}$; $\mathrm{F}_{2}=0.0249 \mathrm{X}_{1}+0.0267 \mathrm{X}_{2}+0.0329 \mathrm{X}_{3}+\ldots+0.0216 \mathrm{X}_{21}$; ...

$\mathrm{F}_{7}=0.0162 \mathrm{X}_{1}+0.0567 \mathrm{X}_{2}+0.0031 \mathrm{X}_{3}+\ldots+0.0023 \mathrm{X}_{21} ;$ $\mathrm{F}_{8}=0.0266 \mathrm{X}_{1}+0.0908 \mathrm{X}_{2}+0.0621 \mathrm{X}_{3}+\ldots+0.7027 \mathrm{X}_{21}$.

\subsection{Logistic regression analysis}

The eight main factors obtained from factor analysis were used as independent variables, and the credit risk rating of manufacturing SMEs was used as dependent variables for logistic regression analysis. Forward stepwise regression was used for regression analysis. The data of credit risk comes from the credit rating of 11315 national enterprise credit information system and national enterprise credit information publicity system, with $Z=0$ for those with bad credit records and $z=1$ for those without.
Table9. Logistic model regression equation variable parameter estimation table.

\begin{tabular}{|c|c|c|c|c|c|}
\hline & B & $\begin{array}{c}\text { Robust. } \\
\text { S.E }\end{array}$ & $\mathrm{z}$ & Sig. & $\operatorname{Exp}(\mathrm{b})$ \\
\hline $\mathrm{F}_{3}$ & $1.617^{*}$ & -0.865 & 1.87 & 0.061 & $5.039^{*}$ \\
\hline $\mathrm{F}_{5}$ & 0.367 & -0.239 & 1.54 & 0.125 & 1.443 \\
\hline $\mathrm{F}_{6}$ & $-2.065^{*}$ & -1.14 & - & 0.07 & $0.127^{*}$ \\
\hline Constant & $1.118^{* *}$ & -0.516 & 2.17 & 0.03 & $3.058^{* *}$ \\
\hline
\end{tabular}

Through the forward stepwise regression method, the final model only contains three variables $F_{3}, F_{5}$ and $F_{6}$, which reflects that the indicators of $F_{3}, F_{5}$ and $F_{6}$ have a significant impact on the credit risk of agricultural small and medium-sized enterprises. The regression equation is as follows:

$$
\begin{gathered}
\ln \frac{p}{1-p}=1.118+1.617 F 3+0.367 F 5-2.065 F 6 \\
p=\frac{1}{1+e^{-(1.118+1.617 F 3+0.367 F 5-2.065 F 6)}}
\end{gathered}
$$


The value of $\mathrm{P}$ can be used to evaluate the credit risk of financing enterprises. If the predicted value $p>0.5$, it means that the performance probability of the enterprise is higher and the financing credit risk of the enterprise is lower; On the contrary, if $\mathrm{P}<0.5$, it means that the higher the credit risk of enterprise financing, the lower the probability of performance. The regression coefficients of the three factors are 1.617, 0.367 and-2.065, respectively. It can be seen that the influence of the three factors on credit risk from strong to weak is comprehensive factor, operation efficiency factor and core enterprise profit factor.

\subsection{Model testing}

In order to test the accuracy of the regression model, the sample data is brought into the test, and the test results are shown in Table 10.

Table10. Results test.

\begin{tabular}{|l|l|c|c|c|c|}
\hline \multirow{3}{*}{} & \multirow{3}{*}{ category } & \multicolumn{2}{|c|}{ Regression model discrimination result } & \multirow{2}{*}{ Total } \\
\cline { 3 - 6 } Back-substitution & \multirow{3}{*}{ count } & 0 & 0 & 1 & \\
\cline { 3 - 6 } & & 1 & 1 & 5 & 9 \\
\cline { 3 - 6 } & \multirow{2}{*}{ proportion } & 0 & $44.44 \%$ & $55.56 \%$ & $100.00 \%$ \\
\cline { 3 - 6 } & 1 & $3.85 \%$ & $96.15 \%$ & $100.00 \%$ \\
\hline & \multicolumn{5}{|c|}{ The total correct rate is $82.86 \%$} \\
\hline
\end{tabular}

Table11. Comparison table of contract performance probability $\mathrm{P}$ and credit risk $\mathrm{Z}$ of sample enterprises (\%).

\begin{tabular}{|c|c|c|c|c|}
\hline ID & $\mathrm{Z}$ & Z_hat & temp2 & temp \\
\hline 1 & 0 & $70.21 \%$ & 1 & 0 \\
\hline 2 & 1 & $81.11 \%$ & 1 & 1 \\
\hline 3 & 1 & $91.20 \%$ & 1 & 1 \\
\hline 4 & 1 & $78.28 \%$ & 1 & 1 \\
\hline 5 & 1 & $82.23 \%$ & 1 & 1 \\
\hline 6 & 0 & $49.95 \%$ & 0 & 1 \\
\hline 7 & 0 & $50.82 \%$ & 1 & 0 \\
\hline 8 & 1 & $94.15 \%$ & 1 & 1 \\
\hline 9 & 1 & $59.62 \%$ & 1 & 1 \\
\hline 10 & 1 & $69.55 \%$ & 1 & 1 \\
\hline 11 & 1 & $97.59 \%$ & 1 & 1 \\
\hline 12 & 1 & $98.63 \%$ & 1 & 1 \\
\hline 13 & 1 & $89.52 \%$ & 1 & 1 \\
\hline 14 & 1 & $96.41 \%$ & 1 & 1 \\
\hline 15 & 1 & $72.77 \%$ & 1 & 1 \\
\hline 16 & 1 & $71.90 \%$ & 1 & 1 \\
\hline 17 & 1 & $89.19 \%$ & 1 & 1 \\
\hline 18 & 1 & $82.00 \%$ & 1 & 1 \\
\hline 19 & 1 & $73.84 \%$ & 1 & 1 \\
\hline 20 & 1 & $47.82 \%$ & 0 & 0 \\
\hline 21 & 0 & $92.23 \%$ & 1 & 0 \\
\hline 22 & 0 & $31.95 \%$ & 0 & 1 \\
\hline 23 & 1 & $81.29 \%$ & 1 & 1 \\
\hline 24 & 1 & $64.88 \%$ & 1 & 1 \\
\hline 25 & 0 & $44.46 \%$ & 0 & 1 \\
\hline 26 & 0 & $6.26 \%$ & 0 & 1 \\
\hline 27 & 1 & $68.28 \%$ & 1 & 1 \\
\hline 28 & 1 & $94.68 \%$ & 1 & 1 \\
\hline 29 & 0 & $88.23 \%$ & 1 & 0 \\
\hline 30 & 1 & $97.99 \%$ & 1 & 1 \\
\hline 31 & 1 & $59.23 \%$ & 1 & 1 \\
\hline 32 & 1 & $79.63 \%$ & 1 & 1 \\
\hline 33 & 1 & $69.28 \%$ & 1 & 1 \\
\hline 34 & 1 & $98.51 \%$ & 1 & 1 \\
\hline
\end{tabular}

(Notes: $\mathrm{Z}$ is the actual situation of default, $\mathrm{z}$-hat is the prediction probability, temp 2 is the prediction of default, and temp is the prediction accuracy) 
It can be seen from table 10 and table 11 that among the 35 selected agricultural enterprises, the $p$ value of the performance probability of 6 enterprises is wrongly estimated, and the overall prediction accuracy of the logistic regression model is $82.86 \%$. Among them, five of the six misjudged enterprises have a $Z$ value of 0 , which may be due to the impact of core enterprise credit on supply chain finance, which improves the financing credit of SMEs to a certain extent, and individual predicted performance probability is higher than the actual rating results. On the whole, the accuracy of using logistic regression analysis to predict the financing credit risk of agricultural SMEs is high.

\section{Research conclusion and suggestion}

\section{1 research conclusion}

This paper makes an empirical study on the credit risk of SMEs financing under the mode of supply chain finance by using logistic regression model. The regression results of the model are tested and the following conclusions are drawn:

Firstly, on the basis of clarifying the financing mode of agricultural supply chain finance, the credit risk evaluation system of agricultural small and medium-sized enterprises is constructed. On the basis of using factor analysis to retain effective information, eight main factors are extracted: profit and property factor, debt repayment factor of financing enterprise, operation efficiency factor, debt repayment factor of core enterprise, profit factor of core enterprise, comprehensive factor, Growth factor and supply chain operation factor. The credit risk evaluation system constructed by the extracted eight main factors can reflect the overall financing ability of enterprises.

Secondly, through the Logistic regression analysis, we can see that operation efficiency factor, profit factor of core enterprise and comprehensive factor have a significant impact on the credit level of financing enterprises. Therefore, in the supply chain business, the credit risk assessment of SMEs should pay more attention to the operational indicators, growth indicators and profitability of related core enterprises.

Thirdly, the results of empirical analysis also show that the prediction accuracy of the model is high, which provides data support for the credit risk assessment of SMEs and helps banks make reasonable loan decisions.

\subsection{Relevant suggestions}

\subsubsection{Commercial banks strengthen the prevention and control of credit risk of the whole supply chain}

The credit risk in the supply chain financial environment is based on the operation of the whole supply chain. Therefore, to control the credit risk of supply chain finance, it is necessary to manage the overall credit risk of the economic activities in which the participants participate. For commercial banks, while providing financing services for small and medium-sized agricultural enterprises, they should verify the trade between enterprises, especially focus on the profitability and liabilities of the core enterprises associated with them, and strengthen the management of cash flow between banks and enterprises. After the loan is issued, it is necessary to carry out regular spot check, with the assistance of the third-party logistics enterprises, to regularly check the trend of loan funds and chattel pledge of financing enterprises, and strengthen the construction of bank information platform.

\subsubsection{Government speed up the construction of basic database}

The imperfection of credit data of small and mediumsized enterprises is the deep reason that affects the further development of supply chain financial model. Therefore, we need to speed up the construction of basic database, collect and sort out credit information and financial information of small and medium-sized enterprises. The government, in collaboration with various administrative units, collates the performance, operation status, tax registration and debt repayment of small and mediumsized enterprises into shared information and establishes a sharing mechanism. Using the credit database construction mode used by banks in the process of credit investigation for reference, and taking advantage of the Internet, a database with real-time update, query and sharing function is established. Relevant departments should also pay attention to the monitoring of information quality and form an efficient credit database system.

\subsubsection{Improve the credit risk assessment model}

In the design process of the model, the enterprise's own factors, the status of mortgage assets under financing, supply chain factors will have an important impact on the supply chain finance. With the arrival of the wave of "mass entrepreneurship, mass innovation" in China, emerging small and medium-sized enterprises continue to appear, and the production and operation status of existing enterprises are constantly changing. Therefore, financial institutions should try to adjust the single main body credit risk assessment index system to comprehensive credit risk assessment index system based on the overall development of supply chain, transform static credit subject assessment into dynamic credit subject evaluation, and update the traditional credit risk assessment model to modern credit risk assessment model. In addition, we need to improve the credit risk assessment system, bring new indicators and parameters into the system, and constantly update the information of supply chain market and operation status, so as to improve the ability of selfiterative update of the system.

\section{References}

1. L. Fan, H.M. Wang, J.X. Shen, Jiangsu Agric. Sci, 43, $10(2015)$ 
2. S.D. Lekkakos, A. Serrano, Int. J. Phys. Distr. Log, 46, 4(2016)

3. H. Song, Q. Lu, K. Yu, J. Manage, 14, 6(2017)

4. F. Jia, T. Y. Zhang, L. J. Chen, J. Clean. Prod, 243(2002)

5. M. Wandfluh, E. Hofmann, P. Schoensleben, Int. J. Logist-res. App, 19, 3(2016)

6. B. Constantin, S. Tobias, Int. J. Prod. Econ, 134, $1(2011)$

7. X. Xiong, J. Ma, Nankai. Manage. Rev, 12, 4(2009)

8. L. M. Xia, H. H. Zong, L. Meng, Fin. For, 16, 10(2011)

9. X. Yang, M. M. Li, A. N. Li, Fin. Econ, 20, 115(2009)

10. S. H. Niu, J. H. Fang, M. Z. Su, Sta. Dec, 1(2017)

11. H. Q. Hu, L. Zhang, D. H. Zhang, Manage. Rev, 24, 11(2012)

12. Y. L. Su, N. Lu, O. J. Social. Sci, 3, 1(2015)

13. W. K. Zhou, C. F. Wang, Oper. Manage. Res, 1(2015)

14. M. Y. Shan, L. L. Chen, R. L. Zhang, Res. Sci. Tech, 35, 13(2015)

15. M. Y. Tian, W. Y. He, Ind. Tech. Econ, 35, 6(2016)

16. B. Hou, S. C. Liu, X. T. Zhuang, Acct. News. 20(2016)

17. D. S. Yu, X. Li, Cr. Invest. 37, 10(2019)

18. H. Song, M. Y. Li, Res. Dev. Manage, 32, 5(2020)

19. G. R. Li, Fin. Theory. Practice, 41, 3(2020)

20. L. T. Shao, M. Zhang, X. Cheng, J. CHS. Agric. Mech, 42, 3(2021)

21. F. Z. Fan, G. Q. Su, X. Y. Wang, J. Cen. Univ. Fin. Econ, 12(2017)

22. Y. Y. Chen, Sta. Dec, 1(2012) 